\title{
NOTES ON TWO NEW GENERA OF PSOCIDAE.
}

BY BARON E. DE SELYS-LONGCHAMPS.

Last year, in preparing for the 'Société entomologique de Belgique' a revision of the 'Psocides' described by Rambur (a paper not yet published), I noticed two genera (or sub-genera) which were not included among the twenty-one genera characterized by Dr. Hagen in his 'Psocinorum Synopsis synonymica' in 1866. I communicated the types of these to my friend, Mr. MeLachlan, not having absolute confidence in my own eyes concerning the existence, or non-existence, of the third tarsal joint in some Psocida. He agreed with my opinion, and, in an article published in the 'Entom. Monthly Magazine' for September last, he notices (Notes 3 and 4, p. 77) the two new forms which I had sent to him, but, from motives of delicacy, refrained from giving them names. However, the few words he gave suffice to establish their diagnosis. It remains then to make known the names which I assign to these new forms, and to give drawings of the neuration of the wings; for, as Mr. MeLachlan has said, it is very desirable that such drawings should be published, because we know by experience how difficult it is for a student, commencing his studies of the Psocida, to follow descriptions of the peculiarities presented by neuration, without the aid of figures.

\section{PSYLLIPSOCUS, $n . g$.}

Alarum anticarum characteres fere ut in Cacilio Elipscocoque; sed vena furcata
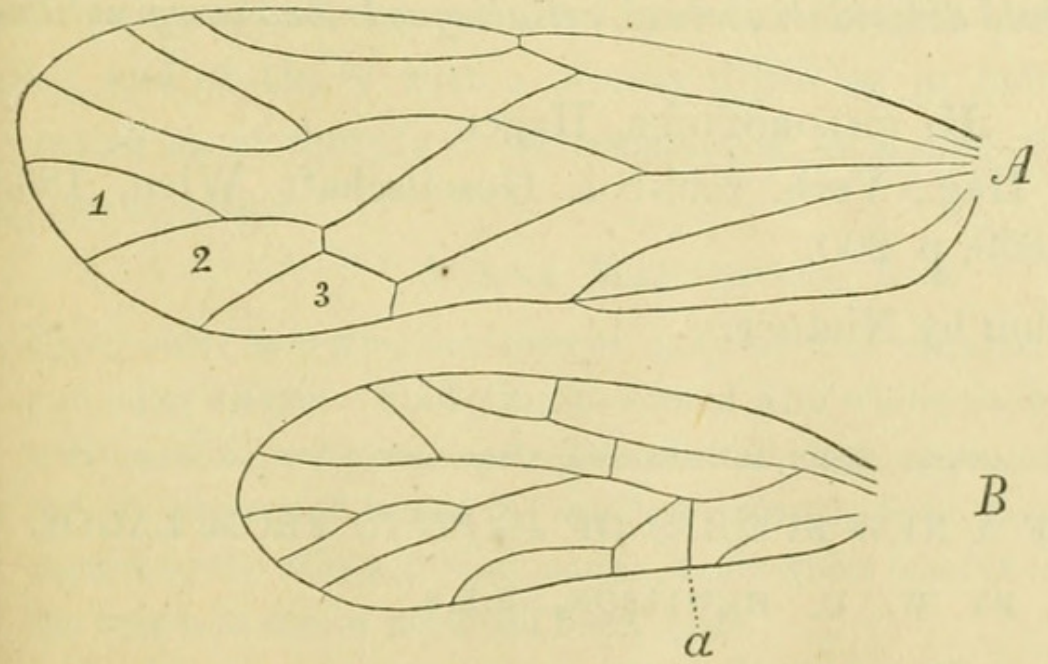

A. Fore-wing of Hemipsocus; 1, 2, 3, the marginal cells.

B. Fore-wing of Psyllipsocus: $a$, the additional branch of the vena furent ramulam (" a" in fig.), cellulam marginalem superadditam, cellula ellipticati ad marginem interiorem basin propius con$B$ junctam formantem, ante furcam primariam infernè emittit. Tarsi, ut in Elipscoco, tri-

articulati. 


\section{P. Ramburit, Selys.}

Psocus pedicularius, Ramb., Névrop., p. 323 (excl. syn.).

Dr. Rambur indicates this insect as found at Paris in houses. The type, now in my collection, is in bad condition, which renders it still more necessary that a drawing of the neuration should be given. Rambur was mistaken in considering this species identical with the pedicularius of Linné, \&c. (= binotatus, Rambur). It is therefore necessary to give it a new name, and I cannot do better than dedicate it to that observant entomologist. It is probable that P. Ramburii is exotic, imported into Paris with plants or merchandize. Rambur having no doubt described the insect from living or fresh examples, it is useful to reproduce his description in order to facilitate new researches :-

"De la grandeur du binotatus, mais ayant les ailes beaucoup plus "grandes. Corps d'un verdâtre obscur, surtout en dessus. Bouche "très-pâle; antennes beaucoup moins longues que l'insecte avec “ses ailes, pâles, legèrement velues; yeux saillaints, noirs. Pieds "pâles. Ailes grandes, tout à fait transparentes, ayant les nervures "fines." (The description of the neuration is not here reproduced, because the terminology does not accord with that now in use. It suffices to say that Rambur was perfectly aware that the nervures are disposed differently to those of other species, and that his description of them agrees entirely with the type in his collection).

\section{HEMIPSOCUS, $n \cdot g$.}

Alarum anticarum characteres ut in Psoco (sensû stricto), sed cellula marginales tres solum (nec quatuor) adsunt. Tarsi, ut in Psoco Peripsocoque, bi-articulati.

A Peripsoco cellulâ discoidali occlusâ, cellulisque tribus marginalibus, discedit.

H. chloroticus, Hagen,

Psocus chloroticus, Hag., Verh. zool-bot. Gesellschaft Wien, 1858, p. $474 ; 1859$, p, 200.

Sent from Ceylon by Nietner.

Liège: October, 1872.

DESCRIPTION OF A NEW SPECIES OF PAPILIO FROM LAGOS.

$$
\begin{gathered}
\text { BY w. c. Hewitson, F.L.s. } \\
\text { Papilio KiRbit, sp. } n \text {. }
\end{gathered}
$$

Upper-side dark brown. Both wings crossed by a central narrow equal band of white, commencing near the apex of the anterior wing, 


\section{$2 \mathrm{BHL}$ Biodiversity Heritage Library}

Sélys-Longchamps, Michel-Edmond. 1872. "Notes on two new genera of Psocidae." The Entomologist's monthly magazine 9, 145-146.

https://doi.org/10.5962/bhl.part.4728.

View This Item Online: https://www.biodiversitylibrary.org/item/36494

DOI: https://doi.org/10.5962/bhl.part.4728

Permalink: https://www.biodiversitylibrary.org/partpdf/4728

\section{Holding Institution}

Smithsonian Libraries

\section{Sponsored by}

Smithsonian

\section{Copyright \& Reuse}

Copyright Status: NOT_IN_COPYRIGHT

This document was created from content at the Biodiversity Heritage Library, the world's largest open access digital library for biodiversity literature and archives. Visit BHL at https://www.biodiversitylibrary.org. 